\title{
Streptomyces brevispora sp. nov. and Streptomyces laculatispora sp. nov., actinomycetes isolated from soil
}

\author{
Tiago Domingues Zucchi, ${ }^{1,2}$ Byung-yong Kim, ${ }^{1,3}$ \\ Jenileima Devi Kshetrimayum, ${ }^{1}$ Hang-Yeon Weon, ${ }^{3}$ \\ Soon-Wo Kwon ${ }^{3}$ and Michael Goodfellow ${ }^{1}$ \\ ${ }^{1}$ School of Biology, University of Newcastle, Newcastle upon Tyne NE1 7RU, UK \\ ${ }^{2}$ Departamento de Entomologia and Acarologia, ESALQ, Universidade de São Paulo, Piracicaba, Brazil \\ ${ }^{3}$ Korean Agricultural Culture Collection, National Academy of Agricultural Science, \\ Rural Development Administration, Suwon 441-707, Republic of Korea
}

Correspondence

Michael Goodfellow

m.goodfellow@ncl.ac.uk
The genus Streptomyces encompasses nearly 600 described species (Euzéby, 2011), members of which are the source of a broad range of secondary metabolites, notably antibiotics (Bérdy, 2005; Goodfellow \& Fiedler, 2010). The subgeneric classification of the genus, while complex, is being improved by the application of genotypic and phenotypic procedures (Lanoot et al., 2005; Goodfellow et al., 2007; Rong \& Huang, 2010). These procedures are also effective in the reassignment of misclassified species of the genus Streptomyces (Tamura et al., 2008; Kumar \& Goodfellow, 2010) and in the recognition of new members of the taxon isolated from diverse natural habitats (Semêdo et al., 2004; Xu et al., 2006; Xiao et al., 2009; Zhao et al., 2010).

The present investigation was designed to establish the taxonomic positions of two Streptomyces strains isolated from a hay meadow soil sample. A polyphasic taxonomic study based on a combination of genotypic and phenotypic procedures showed that isolates $\mathrm{BK} 160^{\mathrm{T}}$ and $\mathrm{BK} 166^{\mathrm{T}}$ should be recognized as two novel species of the genus Streptomyces, Streptomyces brevispora sp. nov. and Streptomyces laculatispora sp. nov., respectively.

Strains $\mathrm{BK} 160^{\mathrm{T}}$ and $\mathrm{BK} 166^{\mathrm{T}}$ were isolated on starchcasein agar (Küster \& Williams, 1964), supplemented with

The GenBank/EMBL/DDBJ accession numbers for the 16S rRNA gene sequences of strains $B K 160^{\top}$ and $B K 166^{\top}$ are $\mathrm{FR} 692104$ and FR692106, respectively. cycloheximide and nystatin (at $25 \mu \mathrm{g} \mathrm{ml}^{-1}$ ), which had been inoculated with a pre-heated $\left(55^{\circ} \mathrm{C}\right.$ for $\left.20 \mathrm{~min}\right)$ soil suspension and incubated at $28{ }^{\circ} \mathrm{C}$ for 21 days. The soil sample was collected from Palace Leas meadow hay plot 6 (Atalan et al., 2000) at Cockle Park Experimental Farm, Northumberland, UK (National Grid reference NZ 200913). The organisms were maintained on oatmeal agar slopes (International Streptomyces Project - ISP medium 3; Shirling \& Gottlieb, 1966) at $4{ }^{\circ} \mathrm{C}$ and as mixtures of mycelial fragments and spores in $20 \%(\mathrm{v} / \mathrm{v})$ glycerol at $-80{ }^{\circ} \mathrm{C}$. Biomass for the chemotaxonomic and molecular systematic studies was grown in shake flasks of tryptoneyeast extract broth (ISP medium 1; Shirling \& Gottlieb, 1966) for 7 days at $28{ }^{\circ} \mathrm{C}$, harvested by centrifugation and washed twice in distilled water; cells for the chemotaxonomic studies were freeze-dried.

Genomic DNA was extracted from the isolates and PCR amplification and 16S rRNA gene sequencing achieved using procedures described previously (Kim et al., 1996). The resultant, almost complete 16S rRNA gene sequences (1439 to $1457 \mathrm{nt}$ ) were aligned manually against corresponding sequences of representatives of the genus Streptomyces using MEGA 4 software (Tamura et al., 2007). Phylogenetic trees were inferred by using the maximum-likelihood (Felsenstein, 1981), maximum-parsimony (Fitch, 1971) and neighbourjoining (Saitou \& Nei, 1987) tree-making algorithms drawn from the MEGA 4 (Tamura et al., 2007) and PHYML (Guindon 
\& Gascuel, 2003) packages. The Jukes \& Cantor (1969) model was used to generate evolutionary distance matrices for the neighbour-joining data. Topologies of the resultant trees were evaluated by bootstrap analysis (Felsenstein, 1985) of the neighbour-joining method based upon 1000 replicates using MEGA 4 software. Kitasatospora griseola JCM $3339^{\mathrm{T}}$ (GenBank accession no. U93320) was used as the outgroup.

Isolates $\mathrm{BK} 160^{\mathrm{T}}$ and $\mathrm{BK} 166^{\mathrm{T}}$ formed a distinct subclade in the Streptomyces 16S rRNA gene tree together with the type strain of Streptomyces drozdowiczii, a taxon which was supported by all tree-making algorithms and by a bootstrap value of $74 \%$ (Fig. 1). The isolates shared a $16 \mathrm{~S}$ rRNA gene sequence similarity of $99.9 \%$, a value which corresponded to $2 \mathrm{nt}$ differences over 1434 locations. Isolate $\mathrm{BK} 166^{\mathrm{T}}$ is the strain that is most closely related to $S$. drozdowiczii NRRL B-24297 $7^{\mathrm{T}}$; the two organisms share a 16S rRNA gene similarity of $99.4 \%$, a value equivalent to $7 \mathrm{nt}$ differences over 1434 locations. Similarly, isolate $\mathrm{BK} 160^{\mathrm{T}}$ shares a $16 \mathrm{~S}$ rRNA similarity of $99.4 \%$ with the type strain of $S$. drozdowiczii, a value equivalent to 9 nt differences over 1439 sites. The $S$. drozdowiczii subclade is loosely associated with the Streptomyces niveus subclade, which also contains the type strains of Streptomyces laceyi and Streptomyces spheroides; the latter two species have been considered to be synonyms of S. niveus (Tamura et al., 2008).

DNA-DNA relatedness values between the isolates and between them and the type strain of $S$. drozdowiczii were determined using the nitrocellulose membrane filter hybridization procedure described by Seldin \& Dubnau (1985). DNA probes were labelled using the non-radioactive digoxigenin (DIG) High Prime System (Roche), hybridized DNA visualized using a DIG luminescent detection kit (Roche), and DNA-DNA relatedness quantified using a densitometer (Bio-Rad). The resultant data showed that all of the strains belong to different genomic species as they shared DNA-DNA relatedness values between 25.6 and $54.5 \%$ (Table 1); values well below the $70 \%$ cut-off point recommended for the assignment of strains to the same genomic species (Wayne et al., 1987). The two most closely related strains, isolates $\mathrm{BK} 160^{\mathrm{T}}$ and $\mathrm{BK} 166^{\mathrm{T}}$, shared a DNA-DNA relatedness value of $54.5 \%$.

Isolates $\mathrm{BK} 160^{\mathrm{T}}$ and $\mathrm{BK} 166^{\mathrm{T}}$ were examined for chemical markers considered to be characteristic of strains of the genus Streptomyces. Standard procedures were used to determine the isomers of diaminopimelic acid (Hasegawa et al., 1983), predominant menaquinones (Collins, 1985), muramic acid type (Uchida et al., 1999) and diagnostic whole-cell sugars (Hasegawa et al., 1983), using appropriate controls. Fatty acids from the isolates and from $S$. drozdowiczii NRRL B-24297 ${ }^{\mathrm{T}}$ were extracted, methylated and analysed by GC using the standard Sherlock Microbial Identification (MIDI) system, version 5 (MIDI, 1999; Sasser, 1990). The DNA base composition of the isolates was determined using the procedure described by Gonzalez \& Saiz-Jimenez (2002).

Isolates $\mathrm{BK} 160^{\mathrm{T}}$ and $\mathrm{BK} 166^{\mathrm{T}}$ contained major amounts of LL-diaminopimelic acid but lacked diagnostic sugars in whole-organism hydrolysates (wall chemotype I sensu Lechevalier \& Lechevalier, 1970), contained $N$-acetylated muramic acid, and containined hexa- and octahydrogenated menaquinones with nine isoprene units [MK-9 $\left.\left(\mathrm{H}_{6}, \mathrm{H}_{8}\right)\right]$ as predominant isoprenologues in a ratio of $5: 1$ and $4: 2$, respectively. The cellular fatty acid profiles consisted mainly of saturated straight-chain and iso- and anteiso-branchedchain components (Table 2), hence all three strains belong to fatty acid type 2c sensu Kroppenstedt (1985); the fatty acid composition of the $S$. drozdowiczii strain was found to be similar to that recorded by Semêdo et al. (2004). The DNA $\mathrm{G}+\mathrm{C}$ content of each of the isolates was $69.2 \%$. All of these properties support the classification of the strains in the genus Streptomyces (Williams et al., 1983; Manfio et al., 1995; Anderson \& Wellington, 2001).

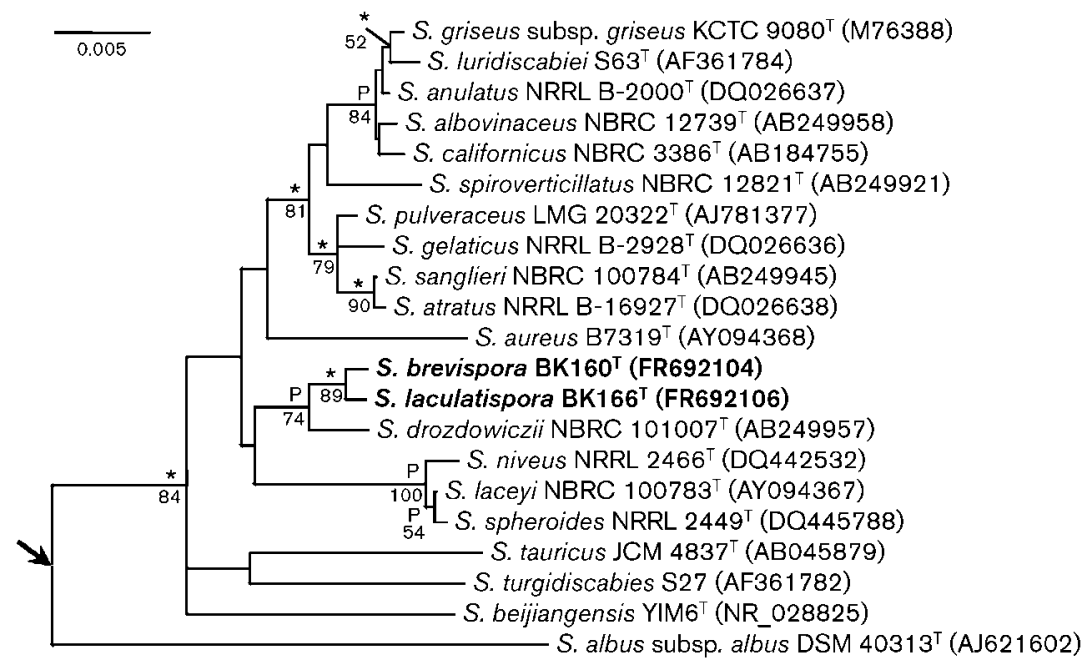

Fig. 1. Neighbour-joining tree based on nearly complete 16S rRNA gene sequences showing relationships between isolates $B K 160^{\top}$ and BK $166^{\top}$ and between them and strains of phylogenetically close species of the genus Streptomyces. Asterisks indicate branches of the tree that were also recovered with the maximum-likelihood and maximum-parsimony tree-making algorithms; $\mathrm{P}$ indicates branches which were also recovered with the maximumparsimony tree-making algorithm. Numbers at nodes are percentage bootstrap values based on 1000 resampled datasets; only values above $50 \%$ are given. Arrow indicates the inferred root position using Kitasatospora griseola JCM $3339^{\top}$ (GenBank accession no. U93320) as outgroup. Bar, 0.005 substitutions per nucleotide position. 
Table 1. 16S rRNA gene sequence similarities and DNA-DNA relatedness values between isolates BK160 ${ }^{\top}, \mathrm{BK} 166^{\top}$ and S. drozdowiczii NRRL B-24297

Values above the diagonal are DNA-DNA relatedness values (\%) whereas those below the diagonal are nucleotide difference/16S rRNA gene sequence similarities (\%).

\begin{tabular}{|lccc|}
\hline Strain & BK160 $^{\mathbf{T}}$ & BK166 $^{\mathbf{T}}$ & S. drozdowiczii NRRL B-24297 $^{\mathbf{T}}$ \\
\hline $\mathrm{BK}^{\mathbf{2} 60^{\mathrm{T}}}$ & - & 54.5 & 30.2 \\
${\mathrm{BK} 166^{\mathrm{T}}}^{\mathrm{T}}$ & $2 / 99.9$ & - & 25.6 \\
S. drozdowiczii NRRL B-24297 & & - \\
\hline
\end{tabular}

The isolates were examined for cultural and morphological features following growth on several standard media for three weeks at $28{ }^{\circ} \mathrm{C}$. Cultural properties were sought using glucose-yeast extract-malt extract (GYM; DSMZ medium 65) and modified Bennett's (Jones, 1949) agars, and on oatmeal, inorganic salts-starch, glycerol-asparagine and tyrosine agars (ISP media 3, 4, 5 and 7; Shirling \& Gottlieb, 1966). Spore arrangement and spore surface

Table 2. Diagnostic characteristics of strains $B K 160^{\top}$ and $B K 166^{\top}$ and their closest phylogenetic relatives in the genus Streptomyces

Strains: 1, isolate BK160 ${ }^{\mathrm{T}}$; 2, isolate BK166 ${ }^{\mathrm{T}}$; 3, S. drosdowiczii NRRL B-24297 ${ }^{\mathrm{T}}$. +, Positive; -, negative.

\begin{tabular}{|c|c|c|c|}
\hline Characteristic & 1 & 2 & 3 \\
\hline \multicolumn{4}{|l|}{ Appearance on inorganic salt-starch agar } \\
\hline Spore-mass colour & None & White & Grey \\
\hline Substrate mycelium colour & White & Pale yellow & Yellow-brown \\
\hline Production of soluble pigment & - & - & + \\
\hline Melanin production on tyrosine agar & - & + & + \\
\hline \multicolumn{4}{|l|}{ Degradation tests } \\
\hline Arbutin & + & + & - \\
\hline Cellulose & - & - & + \\
\hline Elastin & + & + & - \\
\hline Xanthine & + & + & - \\
\hline Xylan & + & + & - \\
\hline \multicolumn{4}{|l|}{ Enzyme activity } \\
\hline Allantoin hydrolysis & - & + & - \\
\hline Pectin hydrolysis & - & - & + \\
\hline \multicolumn{4}{|l|}{ Growth on sole carbon sources } \\
\hline L-Arabinose & - & + & + \\
\hline D-Mannose & + & - & + \\
\hline D-Xylose & + & + & - \\
\hline L-Rhamnose & - & + & - \\
\hline D-Mannitol & + & + & - \\
\hline myo-Inositol & + & + & - \\
\hline Growth at $37^{\circ} \mathrm{C}$ & + & - & + \\
\hline \multicolumn{4}{|l|}{ Tolerance of $\left(\mu \mathrm{g} \mathrm{ml}^{-1}\right)$ : } \\
\hline Streptomycin sulphate (16) & - & + & - \\
\hline Rifampicin (5) & - & - & + \\
\hline Kanamycin sulphate $(30)$ & - & + & - \\
\hline Vancomycin hydrochloride $(0.25)$ & - & - & - \\
\hline \multicolumn{4}{|l|}{ Major fatty acids (expressed as \%) } \\
\hline iso- $\mathrm{C}_{14: 0}$ & 4.9 & 5.5 & 6.0 \\
\hline anteiso- $\mathrm{C}_{15: 0}$ & 36.4 & 29.5 & 18.0 \\
\hline iso- $\mathrm{C}_{15: 0}$ & 5.9 & 10.1 & 19.0 \\
\hline $\mathrm{C}_{16: 0}$ & 8.5 & 9.0 & 6.0 \\
\hline iso- $\mathrm{C}_{16: 0}$ & 19.9 & 18.5 & 22.0 \\
\hline anteiso- $\mathrm{C}_{17: 0}$ & 12.6 & 8.9 & 7.0 \\
\hline iso- $\mathrm{C}_{17: 0}$ & 3.2 & 4.7 & 10.0 \\
\hline
\end{tabular}


ornamentation were observed by examining gold-coated, dehydrated preparations from the ISP 3 cultures, using a scanning electron microscope (Cambridge Stereoscan 240 instrument) and the procedure described by O'Donnell et al. (1993).

Isolate $\mathrm{BK} 160^{\mathrm{T}}$ formed a branched white substrate mycelium and sparse white aerial hyphae which differentiated into straight to flexuous (Rectiflexibilis) chains of smooth-surfaced spores on oatmeal agar (Fig. 2a). The organism grew well on ISP 7, did not grow on GYM agar and grew poorly on all of the other media. Similarly, isolate BK166 ${ }^{\mathrm{T}}$ produced an extensive branched light-brown substrate mycelium and abundant greyish aerial hyphae which differentiated into straight to flexuous chains of square-like smooth-surfaced spores on oatmeal agar (Fig. $2 \mathrm{~b})$. This organism grew well on all remaining media producing light-brown soluble pigments on ISP 3, ISP 5 , ISP 7 and modified Bennett's agars.

The isolates and the type strain of $S$. drozdowiczii were examined for a range of phenotypic properties using media and methods described by Williams et al. (1983). It can be seen from Table 2 that strains $\mathrm{BK} 160^{\mathrm{T}}$ and $\mathrm{BK} 166^{\mathrm{T}}$ can be readily distinguished from one another and from $S$. drozdowiczii NRRL B-24297 ${ }^{\mathrm{T}}$ using a combination of
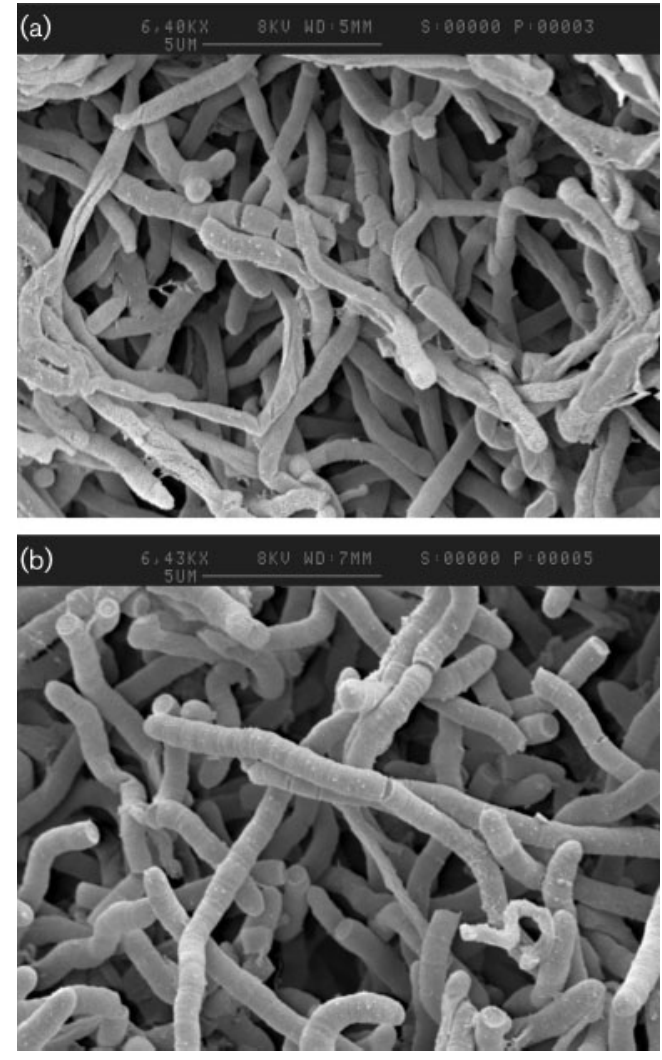

Fig. 2. Electron micrograph of (a) strain $B K 160^{\top}$ and (b) strain BK $166^{\top}$ grown on an oatmeal agar for 3 weeks at $28^{\circ} \mathrm{C}$. Bars, $5 \mu \mathrm{m}$. phenotypic properties and by quantitative differences in fatty acid composition (Table 2). Thus, isolate $\mathrm{BK} 166^{\mathrm{T}}$, unlike $\mathrm{BK} 160^{\mathrm{T}}$, hydrolysed allantoin, grew on $\mathrm{L}$-arabinose and L-rhamnose as sole carbon sources, and was tolerant of kanamycin sulphate $\left(30 \mu \mathrm{g} \mathrm{ml}^{-1}\right)$ and streptomycin sulphate $\left(16 \mu \mathrm{g} \mathrm{ml}^{-1}\right)$. Unlike the two isolates, the type strain of $S$. drozdowiczii hydrolysed pectin and degraded cellulose, but not xanthine or xylan. Additional phenotypic properties are cited in the species descriptions.

In conclusion, the genotypic and phenotypic data show that isolates $\mathrm{BK} 160^{\mathrm{T}}$ and $\mathrm{BK} 166^{\mathrm{T}}$ represent two novel species of the genus Streptomyces. It is, therefore, proposed that these organisms be recognized as Streptomyces brevispora sp. nov. and Streptomyces laculatispora sp. nov., respectively.

\section{Description of Streptomyces brevispora sp. nov.}

Streptomyces brevispora (bre.vi.spo'ra. L. adj. brevis small; N.L. n. spora a seed and in biology a spore; N.L. fem. n. brevispora the small spore, referring to the small size of the spores).

Aerobic, Gram-positive, non-acid-alcohol-fast actinomycete which forms a branched substrate mycelium that bears aerial hyphae which differentiate into short, straight chains of smooth-surfaced spores $(0.7-0.8 \times 0.7-0.9 \mu \mathrm{m})$ on oatmeal agar. Grows from 4 to $37^{\circ} \mathrm{C}$ and from pH 5.0 to 9.0 , but not in the presence of $7.0 \%(\mathrm{w} / \mathrm{v}) \mathrm{NaCl}$. Hydrolyses chitin, starch and uric acid, but not guanine or tributyrin. L-Arabitol, cellobiose, D-galactose, D-glucose, maltose, melibiose, D-salicin and D-sorbitol are used as sole carbon sources for energy and growth, but not D-sorbose (at $1 \%, w / v)$ or oxalic acid (at $0.2 \%, w / v)$. Susceptible ( $\mu \mathrm{g} \mathrm{ml}^{-1}$ unless indicated) to: cephaloridine hydrochloride (2), gentamicin sulphate (8), novobiocin (8) and tetracycline hydrochloride (8), but not to ampicillin (4), ciprofloxacin (2), lincomycin hydrochloride (8) or penicillin $\mathrm{G}\left(2 \mathrm{IU} \mathrm{ml} \mathrm{m}^{-1}\right)$. Lysozyme $(0.05 \%, \mathrm{w} / \mathrm{v})$ sensitive. Additional properties are cited in the text and in Table 2. Chemotaxonomic properties are typical of the genus Streptomyces. The DNA G + C content is $69.2 \mathrm{~mol} \%$.

The type strain, BK160 ${ }^{\mathrm{T}}\left(=\mathrm{KACC} 21093^{\mathrm{T}}=\mathrm{NCIMB}\right.$ $\left.14702^{\mathrm{T}}\right)$, was isolated from soil. The species description is based on a single strain and hence serves as the description of the type strain.

\section{Description of Streptomyces laculatispora sp. nov.}

Streptomyces laculatispora (la.cu.la.ti.spo'ra. L. adj. laculatus four-cornered; N.L. n. spora a seed and in biology a spore; N.L. fem. n. laculatispora the four-cornered spore, referring to the square-like spores).

Aerobic, Gram-positive, non-acid-alcohol-fast actinomycete which forms a branched substrate mycelium that carries aerial hyphae which differentiate into short, straight 
chains of smooth-surfaced, square-like spores (0.7$0.8 \times 0.7-0.8 \mu \mathrm{m})$ on oatmeal agar. Grows from 4 to $30{ }^{\circ} \mathrm{C}$, from $\mathrm{pH} 5.0$ to 9.0 , and in the presence of $7.0 \%$ (w/v) $\mathrm{NaCl}$. Hydrolyses casein, starch and uric acid, but not chitin, guanine or tributyrin. L-Arabitol, cellobiose, Dgalactose, D-glucose, maltose, melibiose, D-salicin and Dsorbitol are used as sole carbon sources for energy and growth, but not D-sorbose (at $1.0 \%, \mathrm{w} / \mathrm{v}$ ) or oxalic acid (at $0.2 \%, \mathrm{w} / \mathrm{v})$. Susceptible $\left(\mu \mathrm{g} \mathrm{ml}^{-1}\right.$ unless indicated) to: cephaloridine hydrochloride (2), gentamicin sulphate (8), novobiocin (8) and tetracycline hydrochloride (8), but not to ampicillin (2), ciprofloxacin (2), clindamycin hydrochloride (10), lincomycin hydrochloride (8) or penicillin G $\left(2 \mathrm{IU} \mathrm{ml}^{-1}\right)$. Lysozyme $(0.05 \%, \mathrm{w} / \mathrm{v})$ resistant. Additional properties are cited in the text and in Table 2. Chemotaxonomic properties are typical of the genus Streptomyces. The DNA G + C content is $69.2 \mathrm{~mol} \%$.

The type strain, BK166 ${ }^{\mathrm{T}}\left(=\mathrm{KACC} 20907^{\mathrm{T}}=\mathrm{NCIMB}\right.$ $14703^{\mathrm{T}}$ ), was isolated from soil. The species description is based on a single strain and hence serves as the description of the type strain.

\section{Acknowledgements}

T.D.Z. is grateful to the Conselho Nacional de Desenvolvimento Científico e Tecnológico for a fellowship to study in the UK (Grant 201066/2009-2). The authors are also indebted to Professor Roberto Zucchi (ESALQ/USP, Brazil) for suggesting the names for the new species.

\section{References}

Anderson, A. S. \& Wellington, E. M. H. (2001). The taxonomy of Streptomyces and related genera. Int J Syst Evol Microbiol 51, 797-814.

Atalan, E., Manfio, G. P., Ward, A. C., Kroppenstedt, R. M. \& Goodfellow, M. (2000). Biosystematic studies on novel streptomycetes from soil. Antonie van Leeuwenhoek 77, 337-353.

Bérdy, J. (2005). Bioactive microbial metabolites. J Antibiot (Tokyo) 58, $1-26$.

Collins, M. D. (1985). Isoprenoid quinone analysis in classification and identification. In Chemical Methods in Bacterial Systematics, pp. 267-287. Edited by M. Goodfellow \& D. E. Minnikin. London: Academic Press.

Euzéby, J. P. (2011). List of prokaryotic names with standing in nomenclature. [Last full update 12 February 2011]. http://www. bacterio.cict.fr/.

Felsenstein, J. (1981). Evolutionary trees from DNA sequences: a maximum likelihood approach. J Mol Evol 17, 368-376.

Felsenstein, J. (1985). Confidence limits on phylogenies: an approach using the bootstrap. Evolution 39, 783-791.

Fitch, W. M. (1971). Toward defining the course of evolution: minimum change for a specific tree topology. Syst Zool 20, 406-416.

Gonzalez, J. M. \& Saiz-Jimenez, C. (2002). A fluorimetric method for the estimation of $\mathrm{G}+\mathrm{C}$ mol\% content in microorganisms by thermal denaturation temperature. Environ Microbiol 4, 770-773.

Goodfellow, M. \& Fiedler, H.-P. (2010). A guide to successful bioprospecting: informed by actinobacterial systematics. Antonie van Leeuwenhoek 98, 119-142.
Goodfellow, M., Kumar, Y., Labeda, D. P. \& Sembiring, L. (2007). The Streptomyces violaceusniger clade: a home for streptomycetes with rugose ornamented spores. Antonie van Leeuwenhoek 92, 173-199.

Guindon, S. \& Gascuel, O. (2003). A simple, fast, and accurate algorithm to estimate large phylogenies by maximum likelihood. Syst Biol 52, 696-704.

Hasegawa, T., Takizawa, M. \& Tanida, S. (1983). A rapid analysis for chemical grouping of aerobic actinomycetes. J Gen Appl Microbiol 29, 319-322.

Jones, K. L. (1949). Fresh isolates of actinomycetes in which the presence of sporogenous aerial mycelia is a fluctuating characteristic. J Bacteriol 57, 141-145.

Jukes, T. H. \& Cantor, C. R. (1969). Evolution of protein molecules. In Mammalian Protein Metabolism, vol. 3, pp. 21-132. Edited by H. N. Munro. New York: Academic Press.

Kim, D., Chun, J., Sahin, N., Hah, Y. C. \& Goodfellow, M. (1996). Analysis of thermophilic clades within the genus Streptomyces by $16 \mathrm{~S}$ rRNA ribosomal DNA sequence comparisons. Int J Syst Bacteriol 46, 581-587.

Kroppenstedt, R. M. (1985). Fatty acid and menaquinone analysis of actinomycetes and related organisms. In Chemical Methods in Bacterial Systematics (Society for Applied Bacteriology Technical Series vol. 20), pp. 173-199. Edited by M. Goodfellow \& D. E. Minnikin. New York: Academic Press.

Kumar, Y. \& Goodfellow, M. (2010). Reclassification of Streptomyces hygroscopicus strains as Streptomyces aldersoniae sp. nov., Streptomyces angustmyceticus sp. nov., comb. nov., Streptomyces ascomycinicus sp. nov., Streptomyces decoyicus sp. nov., comb. nov., Streptomyces milbemycinicus sp. nov. and Streptomyces wellingtoniae sp. nov. Int J Syst Evol Microbiol 60, 769-775.

Küster, E. \& Williams, S. T. (1964). Selection of media for isolation of streptomycetes. Nature 202, 928-929.

Lanoot, B., Vancanneyt, M., Hoste, B., Vandemeulebroecke, K., Cnockaert, M. C., Dawyndt, P., Liu, Z., Huang, Y. \& Swings, J. (2005). Grouping of streptomycetes using 16S-ITS RFLP fingerprinting. Res Microbiol 156, 755-762.

Lechevalier, H. A. \& Lechevalier, M. P. (1970). A critical evaluation of the genera of aerobic actinomycetes. In The Actinomycetales, pp. 393405. Edited by H. Prauser. Jena: VEB Gustav Fischer.

Manfio, G. P., Zakrzewska-Czerwinska, J., Atalan, E. \& Goodfellow, M. (1995). Towards minimal standards for the description of Streptomyces species. Biotekhnologiia 8, 228-237.

MIDI (1999). Sherlock Microbial Identification System Operating Manual, version 3.0. Newark, DE: MIDI, Inc.

O'Donnell, A. G., Falconer, C., Goodfellow, M., Ward, A. C. \& Williams, E. (1993). Biosystematics and diversity amongst novel carboxydotrophic actinomycetes. Antonie van Leeuwenhoek 64, 325340.

Rong, X. \& Huang, Y. (2010). Taxonomic evaluation of the Streptomyces griseus clade using multilocus sequence analysis and DNA-DNA hybridization, with proposal to combine 29 species and three subspecies as 11 genomic species. Int J Syst Evol Microbiol 60, 696-703.

Saitou, N. \& Nei, M. (1987). The neighbor-joining method: a new method for reconstructing phylogenetic trees. Mol Biol Evol 4, 406425.

Sasser, M. (1990). Identification of bacteria by gas chromatography of cellular fatty acids, MIDI Technical Note 101. Newark, DE: MIDI Inc.

Seldin, L. \& Dubnau, D. (1985). Deoxyribonucleic acid homology among Bacillus polymyxa, Bacillus macerans, Bacillus azotofixans, and other nitrogen-fixing Bacillus strains. Int J Syst Bacteriol 35, 151-154. 
Semêdo, L. T. A. S., Gomes, R. C., Linhares, A. A., Duarte, G. F., Nascimento, R. P., Rosado, A. S., Margis-Pinheiro, M., Margis, R., Silva, K. R. \& other authors (2004). Streptomyces drozdowiczii sp. nov., a novel cellulolytic streptomycete from soil in Brazil. Int J Syst Evol Microbiol 54, 1323-1328.

Shirling, E. B. \& Gottlieb, D. (1966). Methods for characterization of Streptomyces species. Int J Syst Bacteriol 16, 313-340.

Tamura, K., Dudley, J., Nei, M. \& Kumar, S. (2007). MEGA4: molecular evolutionary genetics analysis (MEGA) software version 4.0. Mol Biol Evol 24, 1596-1599.

Tamura, T., Ishida, Y., Otoguro, M., Hatano, K., Labeda, D., Price, N. P. \& Suzuki, K. (2008). Reclassification of Streptomyces caeruleus as a synonym of Actinoalloteichus cyanogriseus and reclassification of Streptomyces spheroides and Streptomyces laceyi as later synonyms of Streptomyces niveus. Int J Syst Evol Microbiol 58, 2812-2814.

Uchida, K., Kudo, T., Suzuki, K. \& Nakase, T. (1999). A new rapid method of glycolate test by diethyl ether extraction, which is applicable to a small amount of bacterial cells of less than one milligram. J Gen Appl Microbiol 45, 49-56.

Wayne, L. G., Brenner, D. J., Colwell, R. R., Grimont, P. A. D., Kandler, O., Krichevsky, M. I., Moore, L. H., Moore, W. E. C., Murray,
R. G. E. \& other authors (1987). International Committee on Bacterial Systematics. Report of the ad hoc committee on reconciliation of approaches to bacterial systematics. Int $J$ Syst Bacteriol 37, 463-464.

Williams, S. T., Goodfellow, M., Alderson, G., Wellington, E. M. H., Sneath, P. H. A. \& Sackin, M. J. (1983). Numerical classification of Streptomyces and related genera. J Gen Microbiol 129, 1743-1813.

Xiao, J., Wang, Y., Luo, Y., Xie, S. J., Ruan, J.-S. \& Xu, J. (2009). Streptomyces avicenniae sp. nov., a novel actinomycete isolated from the rhizosphere of the mangrove plant Avicennia mariana. Int J Syst Evol Microbiol 59, 2624-2628.

Xu, C., Wang, L., Cui, Q., Huang, Y., Liu, Z., Zheng, G. \& Goodfellow, M. (2006). Neutrotolerant acidophilic Streptomyces species isolated from acidic soils in China: Streptomyces guanduensis sp. nov., Streptomyces paucisporeus sp. nov., Streptomyces rubidus sp. nov. and Streptomyces yanglinensis sp. nov. Int J Syst Evol Microbiol 56, 11091115.

Zhao, G.-Z., Li, J., Qin, S., Huang, H.-Y., Zhu, W.-Y., Xu, L.-H. \& Li, W.-J. (2010). Streptomyces artemisiae sp. nov., isolated from surfacesterilized tissue of Artemisia annua L. Int J Syst Evol Microbiol 60, $27-32$. 